\title{
Spomienka na významného českého ekonóma profesora Michala Mejstř́́ka
}

Významný český ekonóm profesor Michal Mejstřík sa narodil v roku 1952 v Kolíne. Vyštudoval ekonometriu na Vysokej škole ekonomickej v Prahe a neskôr pracoval v Ekonomickom ústave Československej akadémie vied. Titul kandidáta ekonomických vied (CSc.) získal za svoj akademický výskum v oblasti hodnotenia projektov a svoje štúdiá zavŕšil na London School of Economics (1990 - 1991). V roku 1997 získal na Univerzite Karlovej (UK) v Prahe titul profesora ekonómie.

Od počiatku 90. rokov bol jedným z najvýznamnejších českých ekonómov a dlhodobo pôsobil v akademickej sfére. Podiel’al sa napríklad na založení Centra pre ekonomický výskum a postgraduálne vzdelanie (CERGE-EI), v ktorom pôsobil postupne ako vedecký tajomník a neskôr ako výkonný riaditel'. Na Fakulte sociálnych vied UK v roku 1993 založil Inštitút ekonomických štúdiú, ktorý potom až do roku 2010 viedol ako riaditel'. Jeho zásluhou sa z Inštitútu stalo jedno z najprestížnejších ekonomických pracovísk v Českej republike, ktoré sa opakovane umiestňuje v prvej stovke najlepších svetových ekonomických škôl. Viedol tu výskum a prednášal kurzy zamerané na bankovníctvo, správu korporácie, financie a finančné trhy. Publikoval vyše 150 odborných publikácií z oblasti bankovníctva, transformačných procesov, privatizácie a reštrukturalizácie, ktoré majú výrazný ohlas najmä v zahraničí. V roku 2005 bol v článku v časopise Finance a úvěr zaradený do prvej desiatky najvýznamnejších českých ekonómov. Bol členom Spoločnosti európskych univerzít pre finančný výskum (SUERF) a spoluautorom niekol'kých vysokoškolských učebníc bankovníctva. Okrem toho sa zaslúžil o vydanie českého prekladu klasickej učebnice ekonómie od P. Samuelsona a W. Nordhausa, ktorá predstavuje celosvetovo uznávanú učebnicu základov ekonómie.

V ostatnom štvrt'storočí opakovane pôsobil ako externý konzultant medzinárodných organizácií (Európska komisia, Svetová banka, USAID) v rôznych krajinách strednej a východnej Európy a Ázie. Pracoval ako konzultant tiež pre českú vlády a množstvo podnikov a korporácií, či už samostatne alebo cez spoločnost' EEIP, a.s. Okrem finančného a strategického poradenstva pomohol zaviest' do českej legislatívy prax spracovávania hodnotenia dopadov regulácie (RIA), koordinoval spracovanie radu týchto dopadových štúdií a v rokoch 2011 - 2015 predsedal expertnej komisii RIA pri Legislatívnej rade vlády.

Podiel’al sa na desiatkach akvizičných projektov a firemných reštrukturalizácií, z ktorých niektoré, najmä v energetike, patria medzi najvýznamnejšie v rámci stredoeurópskeho regiónu. Napríklad v rokoch 2001 - 2002 spoločne riadil poradenský tím pri zásadnej akvizícii českého plynárenstva skupinou RWE v hodnote 4,1 mld. EUR. Potom poskytoval pre RWE 12 rokov poradenstvo. Po rozdelení RWE pôsobil v rokoch 2016 - 2019 tiež ako poradca dcérskej spoločnosti innogy. V období 2002 - 2008 bol podpredsedom 
dozornej rady v spoločnosti Východočeská plynárenská, bol členom niekol'kých dozorných rád (ČEZ, Severomoravská plynárenská, Západočeská plynárenská). Viedol rad tímov vo firemných reštrukturalizáciách (ČKD Dopravní systémy, Kongresové centrum Praha a i.). Bol predsedom dozornej rady ČSA (2009 - 2011) a neskôr (2011 - 2014) zastával funkciu predsedu dozornej rady novo vzniknutého Českého Aeroholdingu. Viedol úspešný vyjednávací tím s Európskou komisiou pre otázky štátnej pomoci ČSA a vzniku Českého Aeroholdingu.

V rokoch 2009 - 2014 bol členom Národnej ekonomickej rady vlády (NERV), kde zodpovedal za oblast' konkurencieschopnosti a zahraničného obchodu. Pod jeho vedením vznikla v roku 2011 známa štúdia „Rámec stratégie medzinárodnej konkurencieschopnosti “. Kombinovaný tím NERV a Ministerstva priemyslu a obchodu $\check{C} R$, kde bol jedným z lídrov, potom rozpracoval stratégiu medzinárodnej konkurencieschopnosti ČR. V časoch pandémie Covid-19 v ČR bol členom Ekonomického poradného tímu Ústredného krízového štábu a od počiatku bol tiež členom expertnej skupiny KoroNERV-20. V stávajúcej kríze spôsobenej pandémiou Covid-19 videl príležitost' ku zrýchleniu digitalizácie a dynamiky inovácií.

Profesor Mejstř́ik bol dlhoročným členom vedenia - a v rokoch 2011 - 2014 tiež predsedom - International Chamber of Commerce (ICC) Czech Republic a dlhoročným členom World Council ICC a skupiny globálnych poradcov ICC pre hospodársku politiku a G-20. V minulosti pôsobil tiež ako podpredseda Czech Gulf Business Council, Czech-African Business Council a i. Od roku 2016 bol honorárnym konzulom Kórejskej republiky. Zomrel v januári 2021 vo veku 68 rokov na chorobu Covid-19.

Osobne som mal možnost' sa s ním stretnút' prvýkrát na letnej škole ekonómie organizovanej Karlovou univerzitou po roku 1989 a potom na d’alších manažérskych a vzdelávacích akciách a konferenciách. Neskôr sme už spolupracovali na rôznych projektoch a pôsobili spolu napríklad v International Permanent Study Group on Transition and Privatization. Michal Mejstř́k bol vždy plný nápadov a elánu, mal zmysel pre humor, vedel zaujímavo prednášat' a diskutovat', ale tiež dobre organizovat' prácu a komunikovat' s l'ud'mi. Bol obl'úbeným človekom a uznávaným odborníkom. Správa o jeho úmrtí prekvapila a zasiahla nielen mňa. O tom svedčia aj reakcie mnohých českých ekonómov po oznámení tejto smutnej udalosti - napríklad Aleša Michla, Lukáša Kovandu, Aleša Chmelařa či Daniela Beneša. Jeho odchodom stratila nielen česká ekonomická komunita, ale celá česká spoločnost' významnú osobnost'.

Daneš Brzica

Ekonomický ústav SAV

DOI: https://doi.org/10.31577/ekoncas.2021.04.06 